\title{
INNOVATIONS IN THE AGRICULTURAL BUSINESS: PROBLEMS AND PROSPECTS IN UKRAINE
}

\author{
${ }^{1}$ Tetiana Mulyk, Associate Professor, \\ ${ }^{2}$ Yaroslavna Mulyk, Associate Professor, \\ ${ }^{1,2}$ Ukraine, Vinnytsia, Vinnytsia National Agrarian University
}

DOI: https://doi.org/10.31435/rsglobal_ijite/31032020/6959

\section{ARTICLE INFO}

Received 18 January 2020

Accepted 10 March 2020

Published 31 March 2020

\section{KEYWORDS}

innovation,

innovation activity, agrarian business, agricultural enterprise, IT innovations, SWOT-analysis, Ukraine. \begin{abstract}
The main purpose of the research is to determine the role of innovation of agrarian enterprises for their effective management, as well as analysis of the internal and external environment of innovation activity of agrarian enterprises, their threats and opportunities with the help of SWOT-analysis. The systematization of literary sources and approaches to innovative activity of agrarian enterprises made it possible to generalize that the fundamental questions related to the interpretation of the essence of innovations, innovation activity and innovative processes of enterprises, with the specifics of their manifestation in agrarian enterprises, were investigated by domestic and foreign scientists as well as regulated by normative- legal acts. The urgency of solving this scientific problem lies in the fact that the determining factor of the efficiency of economic activity of the enterprise is their innovative development, which is based on the introduction and implementation of innovations, which determine the improvement of its activities, affect the strengthening of its market positions and produce suitable conditions for its development. One of the promising areas for innovations is the agrarian sector. Introduction of innovations in practice in all spheres of agrarian enterprises contributes to: the increase of labor productivity, decrease of expenses and cost of production, saving of various kinds of resources, increase of volumes and improvement of efficiency of agrarian production. The article analyzes the main directions of IT innovations in agrarian business, innovative solutions (products) and opportunities. It is determined, that any agrarian enterprise has its own peculiarities and specificity and requires individual innovative solutions. The management of the company often can easily identify, what is needed to increase the efficiency. And sometimes the services of analysts and IT consultants, who are professionals of their business, and can unmistakably determine the individual needs and decisions, can be useful. The peculiarities of formation and development of innovation process in agriculture were analyzed. A SWOT analysis of innovative activity of agrarian enterprises was conducted, which allowed to identify their strengths (weaknesses) sides, opportunities and threats. The results of the research can be useful for scientists, specialists and heads of agrarian enterprises, teachers of higher educational establishments, postgraduates, students and all those, who are interested in problems of development and efficiency of innovation activity.
\end{abstract}

Citation: Tetiana Mulyk, Yaroslavna Mulyk. (2020) Innovations in the Agricultural Business: Problems and Prospects in Ukraine. International Journal of Innovative Technologies in Economy. 1(28). doi: 10.31435/rsglobal_ijite/31032020/6959

Copyright: (C) 2020 Tetiana Mulyk, Yaroslavna Mulyk. This is an open-access article distributed under the terms of the Creative Commons Attribution License (CC BY). The use, distribution or reproduction in other forums is permitted, provided the original author(s) or licensor are credited and that the original publication in this journal is cited, in accordance with accepted academic practice. No use, distribution or reproduction is permitted which does not comply with these terms.

Introduction. The current economic conditions cause serious problems regarding the effective operation of agricultural enterprises. Inflation processes, a sharp increase in prices and crisis phenomena stimulate agricultural companies to strengthen their market positions (Gutsalenko et al., 2018). The determining factor of the efficiency of the enterprise's economic activity and the strengthening of market positions is their innovative development, which is based on the introduction 
and implementation of innovations, which determine the improvement of its activities, affect the strengthening of its market positions and produce suitable conditions for its development.

In 2019, according to the Global Innovation Index (2019), Ukraine took the 47rd place out of 126 in the ranking of the most innovative countries in the world (Table 1).

Ukraine performs better in Innovation Outputs than Inputs. This year Ukraine ranks 82nd in Innovation Inputs, worse than last year and compared to 2017. As for Innovation Outputs, Ukraine ranks 36th. This position is worse than last year, but better compared to 2017. Ukraine ranks 2nd among the 26 lower middle-income economies. Ukraine ranks 32nd among the 39 economies in Europe.

Table 1. Ukraine's Rankings in Global Innovation Index, 2017 - 2019

\begin{tabular}{|c|c|c|c|}
\hline Years & GII & Innovation Inputs & Innovation Outputs \\
\hline 2017 & 50 & 77 & 40 \\
\hline 2018 & 43 & 75 & 35 \\
\hline 2019 & 47 & 82 & 36 \\
\hline
\end{tabular}

This is the evidence, that the dynamics of innovation activity of domestic enterprises is positive, that is, it has a tendency to increase. One of the promising areas for introduction of innovations is the agrarian sector. Considerable introduction of innovations in practice in all spheres of agrarian enterprises contributes to: the growth of labor productivity, decrease of expenses and cost of production, saving of various kinds of resources, increase of volumes and improvement of efficiency of agrarian production.

The introduction of innovations in agriculture increases the level of state security in terms of food, providing domestic and foreign markets with essential products. In addition, the development of new varieties of plants, animal breeds, approaches to optimal use of resource potential, updating of equipment and technologies, etc. is a guarantee of the competitiveness of agricultural producers, which is a topical issue for Ukraine at this stage (Kirichenko et al., 2008). With the use of innovative products, domestic agricultural enterprises will be able to stabilize production processes in crop and livestock production and compete properly in domestic and foreign markets (Vysochan et al., 2011).

Extremely urgent is the search for such innovative solutions, that would ensure an increase in the efficiency of the functioning of the agrarian sphere in conditions of limited and depleted natural resources. At present, the constant implementation of the latest developments is a guarantee of sustainable development of agriculture (Bilinska, 2015).

Brooks and Loevinsohm (2011) argue that an enhanced farmer capacity and access to information, in whatever way is essential to the development of more effective, local adapted responses to changed circumstances. The capacity to innovate is as central to adaptation to climate change as it always has been, since farmers are constantly adapting to changing circumstances. It is this underlying, quintessentially local capacity that underlies the diversity of agricultural systems and their constituents.

Taking into account the above mentioned, the activation of innovative processes of agrarian business development is one of the priority ways of development, effective management and economic growth.

The fundamental issues, related to the interpretation of the essence of innovation, innovation activity and innovative processes of business entities, with their specifics in agrarian enterprises, were studied by domestic and foreign scientists and regulated by normative and legal acts.

Thus, the basis for the innovative development of enterprises is laid down in the Law of Ukraine "On Innovation Activity" (2002), which defines: innovations - newly created (applied) and (or) improved competitive technologies, products or services, as well as organizational and technical decisions of an industrial, administrative, commercial or other nature that significantly improve the structure and quality of production and (or) the social sphere.

In Ukraine, the Council for the Development of Innovations was formed (2017), it is provided, that it is a temporary consultative and advisory body of the Cabinet of Ministers of Ukraine, formed for the study of problematic issues, related to the implementation of state policy in the field of development of innovations.

In the scientific literature, domestic and foreign scientists investigated:

- the concept of "innovations", "agro-innovations" Krikunenko D. O. (2011), Uniyat L. M. (2018), Donets O. (2013), Rudenko G. R. (2015), Vysochan O. S. et al. (2011), Shpykulyak O. G. et al. (2016); 
- modern problems of implementation of the results of innovative activity Kriкunenko D. O. (2011), Bilinska V. (2015), Rudenko G. R. (2015), Dichenko L. L. (2017), Ayodele O. J. et al. (2019); - the most important barriers and principles of innovation, that restrain the output of an innovative product on the domestic market Krikunenko D.O. (2011);

- peculiarities of innovations in agriculture and their types Koneva T. A. et al. (2016), Belinska V. (2015), Uniyat L. M. (2018), Donets O. (2013), Klerkx L. et al. (2009), Vysochan O.S. et al. (2011), Shpykulyak O.G. et al. (2016), Saranchuk G. M. (2010), Kirichenko V. V. et al. (2008), Ayodele O. J. et al. (2019).

- experience of foreign countries in the development of agricultural enterprises due to the timely introduction of innovations Rudenko G. R. (2015);

- ways of overcoming the crisis of innovative - technological support of agricultural enterprises, the activities of which are aimed at the dynamic development of agriculture in Ukraine Bilinska V. (2015);

- introduction of innovations in the agrarian sector at newly-owned enterprises Gray A. et al. (2004);

- supporting innovation, by examining methods and organizations, and on evaluating innovation, using different yardsticks Faure G. et al. (2018);

- assessing key factors for innovation system performance and demonstrating the use of system thinking in the facilitation of processes of agricultural innovation by means of innovation brokers and reflexive process monitoring Laurens K. et al. (2012);

- shaping agricultural innovation systems responsive to food insecurity and climate change Brooks et al. (2011) etc.

A detailed analysis of the scientists' works and an assessment of the opportunities, problems and prospects for the development and adaptation of innovative solutions of the management of agrarian business in modern economic conditions require more detailed and thorough research.

Materials and Methods. The purpose of the article - research of innovations and innovative activity of agrarian enterprises and the definition of their role for their effective management. Conducting an analysis of the internal and external environment of the innovative activity of agrarian enterprises, their threats and opportunities with the help of SWOT-analysis.

The article is based on general scientific methods of research and special methods. The article uses: historical and logical methods - in studying the evolution of the problem statement and the continuity of its solution, review of literary sources; economic and statistical - in carrying out an analysis of the current state of activity of agricultural enterprises and innovative projects and solutions in agro-industrial production; abstract-logical - for generalization and formation of conclusions. In addition, the article constructs a matrix of SWOT-analysis.

The SWOT framework was first described in detail in the late 1960's by Edmund P. Learned, C. Roland Christiansen, Kenneth Andrews, and William D. Guth in Business Policy, Text and Cases (Irwin, 1969).

SWOT analysis is a process of establishing links between the most characteristic for the enterprise opportunities, threats, strengths (advantages) and weaknesses, the results of which can be further used to formulate and select the enterprise strategies (Saenko, 2006).

Strengths (S) and weaknesses (W) sides are factors of the internal environment of the analysis object, (that is, what the object itself is able to influence); Opportunities $(\mathrm{O})$ and threats $(\mathrm{T})$ are factors of the external environment (that is, what can affect the object from outside and is not controlled by the object at the same time).

The SWOT methodology provides for the prior identification of strengths and weaknesses and the further establishment of interrelationships between them, that can be used to formulate the organization's strategy. So, the SWOT matrix provides the managers with a structured information field, within which they can strategically orient and make management decisions (Malyuk, 2015).

The SWOT analysis matrix might look like this (table 2).

The methodology (SWOT analysis) has the advantage of being used as a 'quick and dirty' tool or a comprehensive management tool, more importantly this is not a decision that has to be made in advanced as one can lead to the other. This flexibility is one of the factors that has contributed to its success, along with many believing it is light weight, due to their lack of its original purpose (Morrison, 2016). 
Table 2. SWOT analysis matrix

\begin{tabular}{|c|c|c|}
\hline SWOT Analysis & $\begin{array}{c}\text { POSITIVE/ HELPFUL to } \\
\text { achieving the goal }\end{array}$ & $\begin{array}{c}\text { NEGATIVE/ HARMFUL/ } \\
\text { RISKS to achieving the goal }\end{array}$ \\
\hline $\begin{array}{c}\text { INTERNAL Origin } \\
\text { facts/ factors of the } \\
\text { organization }\end{array}$ & $\begin{array}{c}\text { Strengths } \\
\text { Things that are good now, } \\
\text { maintain them, build on them and } \\
\text { use as leverage }\end{array}$ & $\begin{array}{c}\text { Things that are bad now, remedy, } \\
\text { change or stop them. }\end{array}$ \\
\hline $\begin{array}{c}\text { EXTERNAL Origin } \\
\text { facts/ factors of the } \\
\text { environment in which the } \\
\text { organization operates }\end{array}$ & $\begin{array}{c}\text { Opportunities } \\
\text { Things that are good for the } \\
\text { future, prioritize them, capture } \\
\text { them, build on them and optimize }\end{array}$ & $\begin{array}{c}\text { Things that are bad for the future, } \\
\text { put in plans to manage them or } \\
\text { counter them }\end{array}$ \\
\hline
\end{tabular}

Source: (Morrison, 2016).

Research results. Ukraine has significant potential for the development of agrarian business. This is mainly due to fertile soils and a fairly favorable climate in most parts of the country. Agriculture of Ukraine is a rather promising area and one of the leaders in exporting products to world markets. In addition, the agrarian sector is the leading driving force for the economic growth of the country and ensuring the wealth of population.

Agriculture is an important industry not only for Ukraine, but also for other countries of the world. So, Ayodele et al. (2019) believes, that agriculture is considered as a business, that can provide a reasonable basis for export of agricultural products, for export to earn further wealth, job creation and country's potential.

Evidence of the fact, that agriculture in Ukraine has a significant potential, can serve the data, shown in Table 3., where it is evident, that with a decrease in the number of enterprises and employees in this sphere, there is a tendency to increase net profit, profitability, wages, gross added value, export of agricultural products.

While agrarian business has improved its results, the use of new technologies in practice is the further a more characteristic attribute of this industry in Ukraine. Innovative activity as note Shpykulyak O. G. and Gritsaenko M. I. (2016), acts as the embodiment of the latest approaches in the theory and practice of farming, providing a comprehensive intensification of agricultural production, resource savings, improving competitiveness of products or the enterprise.

Table 3. The main indicators of activity of enterprises of agrarian business of Ukraine, 2014-2018

\begin{tabular}{|l|c|c|c|c|c|c|}
\hline \multirow{2}{*}{ Indexes } & \multicolumn{5}{|c|}{ Years } & Deviation \\
\cline { 2 - 7 } & 2014 & 2015 & 2016 & 2017 & 2018 & $\begin{array}{c}2018 / 14 \\
\text { years }\end{array}$ \\
\hline Number of enterprises, units. & 46199 & 45379 & 47697 & 45558 & 49208 & 3009 \\
\hline Net profit (loss), mln UAH & 21413,4 & 101912,2 & 89816,3 & 68276,8 & 66878,1 & 45464,7 \\
\hline $\begin{array}{l}\text { The level of profitability of all } \\
\text { activity, \% }\end{array}$ & 9,3 & 30,4 & 25,6 & 16,5 & 13,5 & 4,2 \\
\hline $\begin{array}{l}\text { Number of employees, } \\
\text { thousand persons }\end{array}$ & 596 & 569,4 & 583,4 & 565,1 & 540,5 & $-55,5$ \\
\hline $\begin{array}{l}\text { Average monthly salary of } \\
\text { regular employees of } \\
\text { enterprises, UAH }\end{array}$ & 2556 & 3309 & 4195 & 6057 & 7557 & 5001 \\
\hline $\begin{array}{l}\text { Agricultural products, mln. UAH } \\
\text { (at constant prices in 2010) }\end{array}$ & 251427,2 & 239467,3 & 254640,5 & 249157 & 268570,9 & 17143,7 \\
\hline $\begin{array}{l}\text { Agricultural lands, thousand } \\
\text { hectares }\end{array}$ & 41511,7 & 41507,9 & 41504,9 & 41489,3 & 41489,3 & $-22,4$ \\
\hline Direct investments, mln \$ & 776,9 & 617 & 502,2 & 586,2 & 578,6 & $-198,3$ \\
\hline Gross added value, UAH million & 161145 & 239806 & 279701 & 305194 & 360757 & 199612 \\
\hline $\begin{array}{l}\text { Export of agro-industrial } \\
\text { complex, mln \$ }\end{array}$ & 16668,9 & 14563,1 & 15281,8 & 17756,9 & 18611,8 & 1942,9 \\
\hline $\begin{array}{l}\text { Import of agro-industrial } \\
\text { complex, mln \$ }\end{array}$ & 6059,3 & 3484,4 & 3891,1 & 4301,2 & 5055,5 & $-1003,8$ \\
\hline
\end{tabular}

Source: (State Statistics Service of Ukraine, 2018) 
Agricultural innovation is seen as a co-evolutionary process, i.e. combined technological, social, economic and institutional change (Laurens et al., 2012).

Highlighting the importance of innovations Faure et al. (2018), point out, that innovation is often referred to as one of the main catalysts for more sustainable and inclusive development. In agricultural and food sectors, innovation is characterized not only by specificities, arising from its relation to nature, but also from the wide variety of its stakeholders, ranging from farmers to consumers and including intermediaries, such as research communities and advisory services. Innovation emerges from the interaction between these actors, who mobilize resources and generate knowledge in collaborative mechanisms to generate changes. It encompasses domains as diverse as production practices, market organization, and eating habits. Innovation is closely linked to major development challenges in its various forms: agro-ecological innovation, social innovation, territorial innovation, etc.

Gray A. et al. (2004) identified key economic concepts that help create a framework for assessing the commercial potential of innovations. In particular, the concepts of consumer welfare and individual firm demand elasticities and what determines those elasticities combined with competitor analyses and the resource- based view to determine the innovation's value proposition to the market.

The world experience of agribusiness development shows, that the most competitive are those agricultural enterprise, that constantly use the development of scientific and technological progress, innovative and resource-saving technologies in production, organization and marketing activities in the field of production and sales of final products (Uniyat, 2018).

It should be noted, that the IT sector in Ukraine, which is now on the rise, finds an attractive field of application - agricultural, and such combination between the two industries provides powerful opportunities for innovations.

As notes Dichenko A. L. (2017) now there is a constant introduction of innovations and scientific developments - guarantee of sustainable development of the agricultural enterprises. Selection of crops, genetic engineering, organic agriculture, drop irrigation, space technologies, nanotechnologies, etc. are actively used in crop production. In livestock production, innovative technologies consist in use of biotechnologies, the advanced feeding systems, selection and breeding work, nanotechnologies, electro-and resource-saving technologies. Today, agricultural enterprise, engaged in plant growing and livestock farming, are searching and implementing qualitative innovative solutions, that can increase the efficiency and productivity of their activities. A variety of specialists are working on finding innovations: breeders, technologists, biologists, economists and other specialists. An important place in this direction is given to IT specialists, who, by their decisions, have substantially changed and continue to change the activities of many enterprises and companies in various fields of business, including agrarian ones.

At present, many innovative products operate on the domestic agrarian market in different directions (Table 4).

It should be noted, that this list is not exhaustive. Any agrarian enterprise has its own peculiarities and specificity and requires individual innovative solutions. Often, management can easily identify, what is needed to increase the efficiency. And sometimes the services of analysts and IT consultants, who are professionals of their business and can accurately determine individual needs and decisions, may be useful. Today there are already IT companies, that choose the agro industry as the main branch of their activity (Khomyn, 2017).

As practice confirms, agrarian business and the introduction of innovative activities are carried out under the influence of certain factors, which are caused by the specifics of this industry. Among them: depending on the climatic conditions, seasonality of production, work with living organisms, the main means of production in the agricultural sector are land, the natural attributes of which are associated with climatic conditions, a rather long process of production, etc.

On that, O. Donets (2013) states, that in the management of innovations it is necessary to take into account the requirements not only of economic laws, but also laws of nature: equivalence, indispensability and a combination of life factors, laws of minimum, optimum and maximum. 
Table 4. Main directions of IT innovations in agrarian business

\begin{tabular}{|c|c|c|}
\hline $\begin{array}{l}\text { The } \\
\text { direction of } \\
\text { innovations }\end{array}$ & $\begin{array}{l}\text { Innovative } \\
\text { solutions } \\
\text { (products) } \\
\end{array}$ & Opportunities \\
\hline 1 & 2 & 3 \\
\hline \multirow{3}{*}{ Cartography } & $\begin{array}{l}\text { Digital } \\
\text { thematic } \\
\text { maps }\end{array}$ & $\begin{array}{l}\text { It involves the application of clear boundaries of sites with the } \\
\text { possibility of their correction, you can find out the area of the plot, } \\
\text { the culture, which it is grown, the average fertility or efficiency, the } \\
\text { history of previous crops and many other necessary information } \\
\text { according to the needs of the user. }\end{array}$ \\
\hline & $\begin{array}{l}\text { Digital } \\
\text { models of } \\
\text { relief }\end{array}$ & $\begin{array}{l}\text { Provides mapping of additional relief of land plots. It is possible to } \\
\text { adjust effectively the irrigation system, as well as to carry out } \\
\text { sowing of moisture-tolerant or moisture-resistant plants in the } \\
\text { optimal for this places. }\end{array}$ \\
\hline & $\begin{array}{l}\text { Other } \\
\text { cartographic } \\
\text { solutions }\end{array}$ & $\begin{array}{l}\text { Provides visualization of the dynamics of soil analysis, analysis of } \\
\text { satellite images from the NDVI, creation of crop yield maps, } \\
\text { identification of the most productive and productive plots, tracking the } \\
\text { dynamics of crops, monitoring the state of fields, forecasting yields, etc. }\end{array}$ \\
\hline \multirow{3}{*}{ Logistic } & Navizor.com & $\begin{array}{l}\text { It provides the construction of optimal routes for collecting and } \\
\text { delivering finished products from the purchasers to the warehouse } \\
\text { or plant. Allows you to save fuel, waste time, reduce the risk of } \\
\text { product damage. }\end{array}$ \\
\hline & $\begin{array}{l}\text { Logistic } \\
\text { solutions } \\
\text { with the } \\
\text { integration of } \\
\text { the system } \\
\text { GPS- } \\
\text { monitoring }\end{array}$ & $\begin{array}{l}\text { Allows you to control the movement of the entire rolling stock of } \\
\text { Agrocompany in real time and, accordingly, respond in a timely } \\
\text { manner to significant delays or deviations from the route. }\end{array}$ \\
\hline & $\begin{array}{l}\text { The solution } \\
\text { with the } \\
\text { integration of } \\
\text { the system of } \\
\text { electronic } \\
\text { document } \\
\text { flow }\end{array}$ & $\begin{array}{l}\text { Provides inventory management and efficient procurement } \\
\text { planning, which greatly simplifies the exchange of information } \\
\text { between adjacent units of agrocompany. }\end{array}$ \\
\hline \multirow[b]{2}{*}{$\begin{array}{l}\text { Monitoring } \\
\text { of the } \\
\text { technology } \\
\text { park }\end{array}$} & $\begin{array}{l}\text { GPS - tracking } \\
\text { technology }\end{array}$ & $\begin{array}{l}\text { Provides fixing and recording in the database, calculates the number } \\
\text { of crossed kilometers for reporting periods (day, month, year). }\end{array}$ \\
\hline & Logbook & $\begin{array}{l}\text { Allows the employee to report on their activities in real time and } \\
\text { receive notifications, reminders and warnings about the departure } \\
\text { from the route or excessive hours of work of the vehicle, etc. The } \\
\text { use of log-books also allows photo and video fixation of the } \\
\text { situation at the work place and the immediate transfer of files to the } \\
\text { administration point. }\end{array}$ \\
\hline Planning & $\begin{array}{l}\text { Innovative } \\
\text { decisions in } \\
\text { planning }\end{array}$ & $\begin{array}{l}\text { Provide planning of optimal neighborhood of plants, alternating } \\
\text { plantations, planning of the possibility of mixed plantings and } \\
\text { application of certain rules of optimization of processes. Allow to } \\
\text { minimize dependence on climatic conditions, use weather features in } \\
\text { their favor, automate the irrigation system, plan the fertilization, based } \\
\text { on the analysis of the state of fields, monitor the presents of pests and } \\
\text { plan the application of pesticides, only when it is actually needed. }\end{array}$ \\
\hline $\begin{array}{l}\text { Management } \\
\text { of personnel, } \\
\text { clients, } \\
\text { partners }\end{array}$ & $\begin{array}{l}\text { Specialized } \\
\text { CRM- and } \\
\text { HRM- } \\
\text { systems }\end{array}$ & $\begin{array}{l}\text { Provide an opportunity in online mode to issue instructions to } \\
\text { employees and respond to their requests. In turn, the employee can } \\
\text { create field reports with the attachment of photo or video materials, } \\
\text { it is possible to monitor the activity and efficiency of each employee } \\
\text { in particular, etc. Effective motivational loyalty programs are also } \\
\text { being introduced. }\end{array}$ \\
\hline
\end{tabular}


Continuation of table 4.

\begin{tabular}{|c|c|l|}
\hline $\begin{array}{c}\text { Analytics } \\
\text { and making } \\
\text { rational } \\
\text { decisions }\end{array}$ & $\begin{array}{c}\text { Innovative } \\
\text { solutions in } \\
\text { analytics }\end{array}$ & $\begin{array}{l}\text { Provide calculation of reporting indicators, their comparison with } \\
\text { similar for previous periods, reflection of dynamics, warning about } \\
\text { "bottlenecks" in technological processes. This is a reliable basis for } \\
\text { making effective management decisions. }\end{array}$ \\
\hline $\begin{array}{c}\text { Monitoring } \\
\text { of health and } \\
\text { quality }\end{array}$ & $\begin{array}{c}\text { Innovative } \\
\text { solutions in } \\
\text { animal } \\
\text { husbandry }\end{array}$ & $\begin{array}{l}\text { Allow: to maintain the optimum microclimate in the premises with } \\
\text { animals, to monitor the dynamics of health, weight gain and compliance } \\
\text { of these indicators with the criteria, to automate the planning of the herd } \\
\text { structure, to take into account genealogy and biological cycles in the } \\
\text { planning of reproduction, automatically form a diet, etc. }\end{array}$ \\
\hline Mobility & $\begin{array}{l}\text { Mobile } \\
\text { applications } \\
\text { allow: vehicle tracking and control, driver monitoring, reminders, } \\
\text { necessary information is directly in the hands of the employee } \\
\text { anywhere, at any moment. }\end{array}$ \\
\hline
\end{tabular}

Source: Built by the authors, based on (Khomyn, 2017).

All this determines the special needs of business entities in this area and encourages the use of certain innovative solutions that help to manage more efficiently, increase productivity, optimize the use of available production resources and meet current market needs.

The peculiarities of the formation and development of the innovative process in agriculture were researched by many scientists Kirichenko V. V. et al. (2008), Saranchuk G. M. (2010), Donets O. (2013), Rudenko G. R. (2015) et al.

The most comprehensive list, in our opinion, is presented by Saranchuk G.M. (2010):

1) the diversity of agricultural products and products of their processing, a significant difference in the technologies of their production;

2) significant differentiation of the individual regions of the country under the agrotechnological conditions of production;

3) dependence of technologies, used in agriculture, from natural conditions;

4) the dispersion of agricultural production in a large area;

5) a large difference in the periods of production of certain types of agricultural products;

6) the isolation of agricultural producers from scientific institutions, engaged in the production of scientific and technical products;

7) absence of organizational and economic mechanism of transferring the achievements of science to agricultural commodity producers.

The practical application of innovations in agrarian business has both positive impacts, opportunities and certain risks. In order to evaluate them, it is expedient to analyze a set of factors, that influence the development of the business entity and its innovative activities through SWOT analysis.

The SWOT analysis of innovative activity of agrarian enterprises makes it possible to identify the main strengths (weaknesses), opportunities and threats (Table 5).

Table 5. SWOT-analysis of innovative activity of agrarian enterprises

\begin{tabular}{|l|l|}
\hline \multicolumn{1}{|c|}{ Strengths } & \multicolumn{1}{c|}{ Weaknesses } \\
\hline \multicolumn{1}{|c|}{1} & \multicolumn{1}{c|}{2} \\
\hline - Significant potential for the development of & - lack of clear recommendations for the use of \\
agrarian business and innovative activities; & innovative products; \\
- agrarian sector - the main source of currency & - weak state support, lack of subsidies; \\
receip in Ukraine; & - insufficient financing and significant cost of \\
- key factor in maintaining trade balance; & innovative products; \\
- use of modern agrotechnics; & - high cost of renewal and modernization of \\
- growth of export potential and development & equipment; \\
of trade with the EU; & - high level of physical wear of domestic equipment; \\
- favorable natural and climatic conditions for & - low level of use of robotics; \\
effective agricultural production; & - problems of certification of organic products, \\
- existence of agrarian educational institutions & nano-products; \\
and other research institutions. & - absence of biological means of plant protection; \\
& - weak development of breeding work; \\
& - a significant investment need; \\
& - the need for highly skilled staff, scientists. \\
\hline
\end{tabular}


Continuation of table 5 .

\begin{tabular}{|l|l|}
\hline \multicolumn{1}{|c|}{ Opportunities } & \multicolumn{1}{|c|}{2} \\
\hline - assistance in planning of crops, conducting of & - appearance of carcinogenic and mutagenic \\
electronic agrochemical passports of fields, & effects; \\
drawing up of technological maps, field maps; & - the emergence of unwanted mutations; \\
- control of crop rotation, analysis of the dynamics & - reduction of nutritional properties of products; \\
of crop development, tracking the status of the & - reduction of reproductive capacity; \\
fields and estimating the forecast of yield; & - harmful effect on human health; \\
- automation of calculations of the needs of & - need for retraining of the staff; \\
seeds, fertilizers and plants (animals) protection & - climate change, degradation of arable land \\
products, the formation of planned and actual & through intensive soil cultivation; \\
costs, the formation of analytical reports; & - high interest rates on loans; \\
- automation of planning of the herd structure, & - increase in the cost of mineral fertilizers, energy \\
genealogy accounting and analysis of growth and & carriers, fuel and lubricants, etc.; \\
weight, food rationing and veterinary measures; & - the instability of the agricultural market, which \\
- monitoring of work of the equipment, & makes it impossible to predict the price of \\
accounting of fuel consumption; & agricultural products for the next season; \\
- increase of competitiveness of agricultural & - the instability of the legislative framework. \\
products; & \multicolumn{2}{|l}{} \\
- creation of innovative clusters. & \multicolumn{2}{|c}{} \\
\hline
\end{tabular}

Source: Developed by the authors

The table shows, that the innovative activities of agricultural enterprises are influenced by various factors, which help to assess the modern innovative potential, opportunities and threats, and to identify the features of innovative activity of business entities.

The positive changes in the introduction of innovations in the production of agricultural products include:

1) increase of crop productivity;

2) increase of profitability of the enterprise;

3 ) increase of competitiveness of agricultural products on the domestic and foreign markets;

4) improving the quality of products and saving of productive resources;

5) introduction of energy-saving and resource-saving technologies (Rudenko, 2015).

The problems of introducing innovations in agriculture in Ukraine include the lack of proper financing, low level of state support for enterprises, low level of innovation research in agriculture in Ukraine, seasonal activity of enterprises, a variety of climatic conditions and cultivated products (Rudenko, 2015). Despite the fact that there are significant developments, experience in the innovative activities of agrarian enterprises, there are certain obstacles to its development.

So, Koneva T. A. et al. (2016) considers the main problems of increase in innovative activity in agrarian and industrial complex are lack of the corresponding state policy, the crisis phenomena in agriculture, deficiency and limited of financial resources. Considering it, leasing and cooperation can become the perspective directions of financing of innovations in the sector of agriculture.

We support the opinion of D. O. Krikunenko (2011), who believes, that in order to overcome the barriers on the way of introducing innovations, agrarian enterprises should use the following approaches:

1. To work with innovations a certain group of creative people must be created. Managers should carefully approach the discovery and further unification of creative personalities. It is creativity, the ability to divergent thinking, that positively influence the production and implementation of innovative ideas.

2. Group motivation. The use of material and non-material methods of motivation enables to improve the efficiency of the innovation process as a whole. of the tasks.

3. Planning of work will allow to define clearly the goals and the possibility of further control

4. Control over implementation of tactical and strategic plans of innovative policy, using specially developed evaluation criteria (Krikunenko, 2011).

We believe, that the practical application of such approaches will facilitate the activation of innovative activity.

Having analyzed the possibilities of using and the problems of adaptation of advanced technologies in agriculture, one can conclude, that in order to overcome the low level of innovative- 
technological equipment of the agrarian sector it is necessary to make a number of changes, which, first of all, should concern:

- institutional and legal support, concerning methods of agricultural management;

- intensification of the development of agrarian science and intellectual potential of agroindustrial complex;

- improvement of the level of training and raising the skills of the agrarian sector workers;

- stimulation of state financial support of agricultural enterprises engaged in innovative activity;

- attraction of investments for introduction of scientific and technical achievements in production;

- implementation of corresponding programs and strategies of the development of innovative activity in agriculture;

- development and introduction of effective mechanisms of stimulating of innovations in the agrarian sector;

- state support in the field of breeding, genetic engineering and nanotechnologies;

- formation of organizational and economic mechanism of technological safety of the agrarian sector;

- increase in the competitiveness of agrarian products in the context of eco and bio development, etc. (Bilinska, 2015)

Conclusions. Innovations are an important factor in the efficiency of enterprise management. They influence the improvement of its activities, strengthen market positions and produce suitable conditions for development. A promising industry for innovation is the domestic agrarian sector, which has significant potential. The introduction of innovations in this area will help: to increase labor productivity, reduce costs, save resources, increase production volumes and increase the efficiency of activities.

An important place for the formation of innovations for agrarian business is allocated to the IT sector and IT specialists, which by their decisions change the activities of many agribusinesses and offer various innovative solutions in certain directions.

Experience has shown, that the application in practice of innovations in the agrarian business has both positive effects, opportunities and certain risks. In order to evaluate them, it is expedient to carry out the analysis of internal and external factors, that influence the development of an enterprise and its innovative activity with the help of SWOT-analysis. Such an analysis enabled us to identify the strengths and weaknesses of the innovative activity, its potential and threats.

\section{REFERENCES}

1. Ayodele, O. J., Innocent, I. O., \& Garba, S. J. (2019). Innovation as a Mediating of Relationship Between Internal and External Environment in Agribusiness Performance. Marketing and Management of Innovations, 1, 196-207. doi:10.21272/mmi.2019.1-16.

2. Bilinska, V.Yu. (2015). Modern innovative technologies in agriculture: the main characteristics and prospects of implementation. Herald of the Taras Shevchenko National University, 7 (102), 74-80.

3. Brooks, S., \& Loevinsohn, M. (2011). Shaping agricultural innovation systems responsive to food insecurity and climate change. Natural Resources Forum, 35, 185-200.

4. Dichenko, A.L. (2017). Determination of strategic priorities of development of marketing commodity policy of agricultural enterprises. Scientific herald of the National University of Bioresources and Nature Management of Ukraine, 260, 108-121.

5. Donets, O. (2013). Innovation and its peculiarities in the agrarian sector of Ukraine's economy. Economic analysis, 12 (1), 92-97.

6. Faure, G., Chiffoleau, Y., Goulet, F., Temple, L., \& Touzard, J.-M. (2018). Innovation and development in agricultural and food systems. Versailles: Ed. Quae, (Synthèses: Quae). Retrieved from https://www.quae.com/produit/1540/9782759229604/innovation-and-development-in-agricultural-and-food-systems.

7. Global Innovation Index (2019). Retrieved from https://www.wipo.int/edocs/pubdocs/en/wipo_pub_gii_2019/ua.pdf

8. Gray, A., Boehlje, M., Amanor-Boadu, V. \& Fulton, J. (2004). Agricultural Innovation and New Ventures: Assessing the Commercial Potential. American Journal of Agricultural Economics, 86, 1322-1329. doi:10.1111/j.0002-9092.2004.00684.x.

9. Gutsalenko, L., Wasilewski, M., Mulyk, T., Marchuk, U., \& Mulyk, Ya. (2018) Accounting control of capital investment management: realities of Ukraine and Poland. Economic annals-XXI, 170 (3-4), 79-84. doi:10.21003/ea.V170-14.

10. Irwin, R. J. (1969). Emmert's law as a consequence of size constancy. Perceptual \& Motor Skills, 28, 69-70.

11. Khomyn, A. (2017) IT innovations in agribusiness. 8 key areas worth knowing. Retrieved from http://blog.bvblogic.com/uk/2017/07/07/ 
12. Kirichenko, V.V., \& Tymchuk, V.M. (2008). Market models for implementation of breeding innovations. Herald of Agrarian Science, 8, 62-64.

13. Koneva, T.A., \& Kikla, A.M. (2016). Features of introduction of innovations by agricultural enterprises of Ukraine. Scientific works. Economy, 273, 101-106.

14. Krikunenko, D.O. (2011). Problems of introduction of innovations at enterprises. Marketing and Management of Innovation, 4, 45-49.

15. Laurens, K., Barbara, M., \& Cees, L. (2012). Evolution of systems approaches to agricultural innovation: concepts, analysis and interventions. Farming Systems Research into the 21st Century: The New Dynamic, 457-483. doi:10.1007/978-94-007-4503-2.

16. Malyuk, S.O. (2015). Use of matrix methods of strategic analysis, when forming an assortment strategy of the enterprise. Herald of Kharkiv National University, named after V.V. Dokuchaev, 1, 171-178.

17. Morrison, M. (2016). SWOT analysis (TOWS matrix) Made Simple. Retrieved from https://rapidbi.com/SWOTanalysis/

18. On Innovation Activity: Law of Ukraine. No. 40-IV. (2002).

19. On the formation of the Council for the development of innovations: Resolution of the Cabinet of Ministers of Ukraine. No 895. (2017).

20. Rudenko, G. R. (2015). Peculiarities of introduction of innovations in the activity of agricultural enterprises. Business Inform, 5, 128-132. Retrieved from http://nbuv.gov.ua/UJRN/binf_2015_5_20.

21. Saenko, M.G. (2006). Enterprise Strategy. Ternopil: Economic Thought.

22. Saranchuk, G.M. (2010). Innovative development of agriculture, as a basis for increasing its competitiveness. Innovative economy, 1, 26-32.

23. Shpykulyak, O.G., \& Gritsaenko, M.I. (2016). Development of innovative activity in the agrarian sector: management and efficiency. Kherson: OLDI-PLUS.

24. State Statistics Service of Ukraine (2018). Agriculture, forestry and fishing. Statistical publication. Agriculture of Ukraine. Retrieved from http://ukrstat.org/en/druk/publicat/kat_e/publ4_e.htm

25. Uniyat, L. M. (2018). Theoretical aspects of innovative development of agribusiness. An Economical Internet Conference. World of Economic Science. Ternopil, Ukraine. Retrieved from http://www.economyconfer.com.ua/full-article/2823/.

26. Vysochan, O.S., \& Picush, Yu.V. (2011). Scientific approaches to the definition of the concepts "Innovation" and "Innovative activities" in agriculture. Herald of the Khmelnytsky National University, 2, 101-104. 